\title{
PARTICIPATION OF NO IN THE VASODILATORY ACTION OF ISOESPINTANOL
}

\author{
PARTICIPACIÓN DE NO EN LA ACCIÓN VASODILATADORA DEL ISOESPINTANOL
}

Gustavo J. RINALDI, $\mathrm{PhD}^{1}$; Benjamín ROJANO, $\mathrm{PhD}^{2 \star}$; Guillermo SCHINELLA, MSc ${ }^{3}$; Susana M. MOSCA. PhD ${ }^{4 \star}$

Received: November 06 of 2018. Approved: July 30 of 2019.

\begin{abstract}
Background: accumulating evidence suggests that natural compounds and specifically monoterpenes exert a vasodilator action. Objetive: to investigate the vascular effects of isoespintanol (2-isopropil-3,6dimetoxi-5-metilfenol, ISO) monoterpene isolated from the leaves of Oxandra cf xylopioides. Methods: thoracic aortic rings isolated from Wistar rats were contracted with $\mathrm{KCl} 80 \mathrm{mM}$ and then relaxed by exposure to $\mathrm{Ca}^{2+}$-free solution in absence and in presence of ISO $0.6 \mu \mathrm{g} / \mathrm{mL}$. The force/tissue ratio (F/W) and the time to obtain $50 \%$ of relaxation (T-50) were used to assess the maximal contractile response and the relaxation, respectively. To examine the participation of $\mathrm{NO}$ additional experiments were performed under inhibition of nitric oxide synthase with L-NAME (L-N ${ }^{\mathrm{G}}$-Nitroarginine methyl ester). Results: ISO significantly decreased the F/W ratio $(257 \pm 19$ vs. $360 \pm 18)$ and did not change T-50. In presence of L-NAME the effects of ISO on contractile response was abolished. Conclusions: these results demonstrate that ISO exerts a vasodilator effect through NO-dependent pathways and suggest that an inhibition of calcium influx could be the involved mechanism.
\end{abstract}

Keywords: Isoespintanol, thoracic aorta, nitric oxide (NO).

\section{RESUMEN}

Antecedentes: la evidencia acumulada sugiere que los compuestos naturales, especialmente monoterpenos, ejercen una acción vasodilatadora. Objetivo: investigar los efectos vasculares del monoterpeno isoespintanol (2-isopropil-3,6-dimetoxi-5-metilfenol, ISO) aislado de hojas de Oxandra cf xylopioides. Métodos: anillos de aorta torácica aislados de ratas Wistar fueron contraídas con cloruro de potasio $80 \mathrm{mM}$ y luego relajadas por exposición a una solución libre de $\mathrm{Ca}^{2+}$ en ausencia y presencia de isoespintanol $0,6 \mu \mathrm{g} / \mathrm{mL}$. El radio fuerza/tejido $(\mathrm{F} / \mathrm{T})$ y el tiempo para obtener $50 \%$ de relajación (T50) se usaron para lograr la máxima respuesta contráctil y de relajación, respectivamente. Para evaluar la participación del óxido nítrico, se realizaron experimentos adicionales bajo la inhibición de la óxido nítrico sintetasa con L-NAME (L-NG-éster metílico de nitroarginina). Resultados: Isoespintanol disminuyó el radio F/W significativamente $(257 \pm 19$ vs. $360 \pm 18)$ y no cambió T-50. En presencia de L-NAME, los efectos del isoespintanol en la respuesta contráctil fueron suprimidos. Conclusiones: Estos resultados demuestran que el isoespintanol ejerce un efecto vasodilatador a través de vías $\mathrm{NO}$ dependientes y sugiere que la inhibición de la entrada de calcio puede ser el mecanismo involucrado.

Palabras clave: Isoespintanol, aorta torácica, óxido nítrico (NO).

Facultad de Ciencias Exactas, Universidad Nacional de La Plata. La Plata, Argentina.

Laboratorio de Ciencias de los Alimentos, Facultad de Ciencias, Universidad Nacional de Colombia (sede Medellín). Medellín, Colombia.

Facultad de Ciencias Médicas, Universidad Nacional de La Plata, CIC-PBA, La Plata, Argentina

Centro de Investigaciones Cardiovasculares "Dr Horacio E. Cingolani”, CCT-CONICET, Universidad Nacional de La Plata. La Plata, Argentina.

^ Corresponding authors: brojano@unal.edu.co,smosca@med.unlp.edu.ar. 


\section{INTRODUCTION}

Alterations in the function and structure of the blood vessel wall account for most cardiovascular clinical events. Cardiovascular drugs may exert beneficial effects on the vascular wall both at the level of the endothelium and vascular smooth muscle cells. It has been recognized that endothelial dysfunction is an important early event in the development of various vascular diseases, including hypertension, diabetes, and atherosclerosis. This thin layer of cells that lines the interior surface of all blood vessels, modulates vascular tone by releasing endothelium-derived relaxing factor (EDRF) and contracting factors. Nitric oxide (NO) is the best characterized EDRF and plays a key role in protecting the vascular wall $(1,2)$. NO is produced via endothelial NO synthase (eNOS) and mediates the increase of intracellular cGMP which can inhibit $\mathrm{Ca}^{2+}$ entry into the cell thus producing the smooth muscle relaxation. It is widely accepted that the $\mathrm{Ca}^{2+}$ influx through plasma membrane $\mathrm{Ca}^{2+}$ channels plays an important role in the control of muscle tone (3).

Medicinal plants have been used for millennia for the treatment of diseases, and still many of today's drugs are plant-derived natural products (4). Most of the therapies involve the use of plant extracts or their active compounds, as terpenoids that include their main subclasses mono-, diand tetraterpenes (5). At cardiovascular level, vasorelaxation, decreased heart rate and blood pressure were the main effects of 33 monoterpenes previously reviewed by Márcio et al (6).

Isoespintanol is a monoterpene isolated from leaves of Oxandra $c f$. xylopioides and their anti-inflamatory activity has been previously demonstrated (7). However, the vascular actions of this compound have not yet been examined.

Therefore, the objective of this study was to assess the action of isoespintanol on contraction and relaxation of isolated thoracic aorta rings analyzing the participation of NO.

\section{MATERIALS AND METHODS}

\section{Extraction and identification of isoespintanol}

Isoespintanol was obtained from Oxandra of xylopioides as previously detailed (7). Briefly, dry and ground leaves of this vegetal product were extracted with petroleum ether by percolation and dried by rotary evaporation. The extract was subjected to various chromatographic columns by gravity, eluting with hexane-dichloromethane mixtures and finally recrystallizing. The structure of the compound was established on the basis of the interpretation of its NMR and MS data (8).

\section{Experimental preparation}

All procedures followed during this investigation were approved by the Institutional Animal Care and Use Committee (IACUC) of the Faculty of Medicine, University of La Plata following the Guide for the Care and Use of Laboratory Animals published by the Nacional Research Council, National Academy Press, Washington DC 2010 and/or European Union Directive for Animal Experiments 2010/63/EU.

Wistar rats of 4-5 months years old were anesthetized with an intraperitoneal injection of $25 \%$ urethane $(0.6 \mathrm{~mL}$ by $100 \mathrm{~g})$. The thoracic aorta was removed and placed in physiological salt solution (PSS) containing (in mmol/L): $\mathrm{NaCl}$ 130, $\mathrm{KCl} 4.7, \mathrm{Na}_{2} \mathrm{HPO}_{4} \mathrm{H} 1.17, \mathrm{MgSO}_{4}$ 1.16, $\mathrm{NaHCO}_{3} 24, \mathrm{CaCl}_{2} 1.6$ and dextrose 11. The PSS was saturated with a mixture of $95 \% \mathrm{O}_{2}-5 \% \mathrm{CO}_{2}$, had a $\mathrm{pH} 7.4$, and was maintained at $37^{\circ} \mathrm{C}$. After then, several rings $2-3 \mathrm{~mm}$ wide were obtained from every aorta, but each ring was used for only one experimental protocol. This model has been recently re-validated and considered as a "golden tool" in pharmacological researches (9). Aortic rings were suspended between a fixed point and a force transducer (Grass FT0.03D). A resting tension of $2 \mathrm{~g}$ was imposed by stretching and the preparation was stabilized in PSS for 1 hour prior to any experimental protocol (with one wash every 20 minutes). The signal from the transducer was amplified and entered into a DT2801A analog/ digital board (Data Translation, Inc.) mounted on a personal computer, originating a file using data acquisition software (Labtech Notebook Pro).

\section{Protocols}

Aortic contraction in presence of extracellular $\mathrm{Ca}^{2+}$

Arterial ring contraction was induced through $\mathrm{KCl}$ due to its ability to depolarize cell membranes, and thereby opening voltage-dependent $\mathrm{Ca}^{2+}$ channels. The influx of extracellular $\mathrm{Ca}^{2+}$ into arterial cells occurs through those channels and results in vasoconstriction. In this functional 
study, $80 \mathrm{mM} \mathrm{KCl}$ was added to an organ bath media to induce constant contractions in TA rings after equilibration. Control aortic rings and rings exposed to ISO $0.6 \mu \mathrm{g} / \mathrm{mL}$ for $10 \mathrm{~min}$ were contracted with $\mathrm{KCl}$. To assess the participation of nitric oxide synthase (NOS) L-N ${ }^{G}-\mathrm{Nitro}-\mathrm{L}-$ arginine methyl ester (L-NAME, inhibitior of NOS) $100 \mu \mathrm{mol} / \mathrm{L}$ was added in the last minutes 20 min of stabilization and the aforementioned ISO protocol was repeated. The contractile responses were calculated in $\mathrm{mg}$ of force per $\mathrm{mg}$ of tissue wet weight $(\mathrm{mgF} / \mathrm{mgW})$.

\section{Relaxation aortic in absence of extracellular $\mathrm{Ca}^{2+}$}

The rings were exposed to contracting PSS, and when the force stabilized ( $\sim 10-15$ minutes) the solution was replaced by $\mathrm{Ca}^{2+}$-free relaxing PSS (made by omitting $\mathrm{CaCl}_{2}$ and adding $0.1 \mathrm{mM}$ EGTA), obtaining a relaxation to the baseline. Control rings and rings incubated $10 \mathrm{~min}$ with ISO $30 \mu \mathrm{g} / \mathrm{mL}$, in presence or in absence of NOS inhibition were contracted with $\mathrm{KCl}$ and relaxed in absence of $\mathrm{Ca}^{2+}$. The time to obtain $50 \%$ of relaxation (T-50) was measured. The tracing of relaxation was fitted to a monoexponential curvefitting equation of the form $\mathbf{F}=\boldsymbol{a} \mathbf{e}^{-\mathbf{t} / \boldsymbol{t}}$ where $\mathbf{F}$ is force, $\mathbf{t}$ is time and $\boldsymbol{t}$ is the relaxation time constant.

\section{Statistical analysis}

Data were expressed as means \pm SD. Statistical analysis was performed by one-way analysis of variance (ANOVA) followed by the NewmanKeul's post-test used for multiple comparisons among groups. Values of $p<0.05$ were considered to indicate statistical significance.

\section{RESULTS}

Exposure aortic rings to contracting solution produced a sustained contraction, which relaxed rapidly after switching to $\mathrm{Ca}^{2+}$-free relaxing PSS. The contraction was significantly greater in control than in rings treated with ISO $30 \mu \mathrm{g} / \mathrm{mL}(257 \pm 19$ vs. $360 \pm 18 \mathrm{mgF} / \mathrm{mgW}$ ). Relaxation was similar in control and ISO treated aortic rings, acquiring T-50 equal values in both groups (68 sec, Figure 1).

The curve-fitting analysis of the relaxation curves showed that $\tau$ was similar in control and ISO treated aortic rings $(103 \pm 6$ and $94 \pm 11$ msec, respectively). The inhibition of NOS with L-NAME abolished the decrease of maximal force of contraction observed after ISO addition. The values of $\mathrm{F} / \mathrm{W}$ ratio were $319 \pm 13$ and $346 \pm$ 34 for ISO+L-NAME and control +L-NAME, respectively (Figure $2 \mathrm{~A})$. The $\tau$ values of control and ISO in presence of L-NAME were significantly higher than the same group in absence of NOS inhibition (Figure 2B).

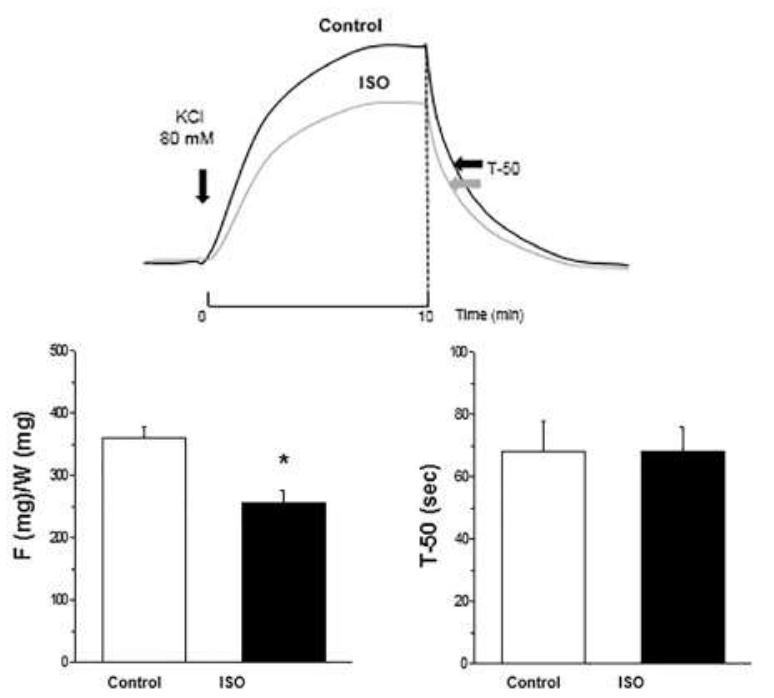

Figure 1. Top panel: Representative tracings of contractions induced in control and ISO treated aortic rings. Bottom panel: Average results of maximal force of contraction $(\mathrm{F} / \mathrm{W})$ and $\mathrm{T}-50$ of relaxation for control and ISO groups. Note that $\mathrm{F} / \mathrm{W}$ decreased and T-50 did not change in ISO compared to control aortic rings. ${ }^{\star} \mathrm{p}<0.05$ ISO vs. Control.
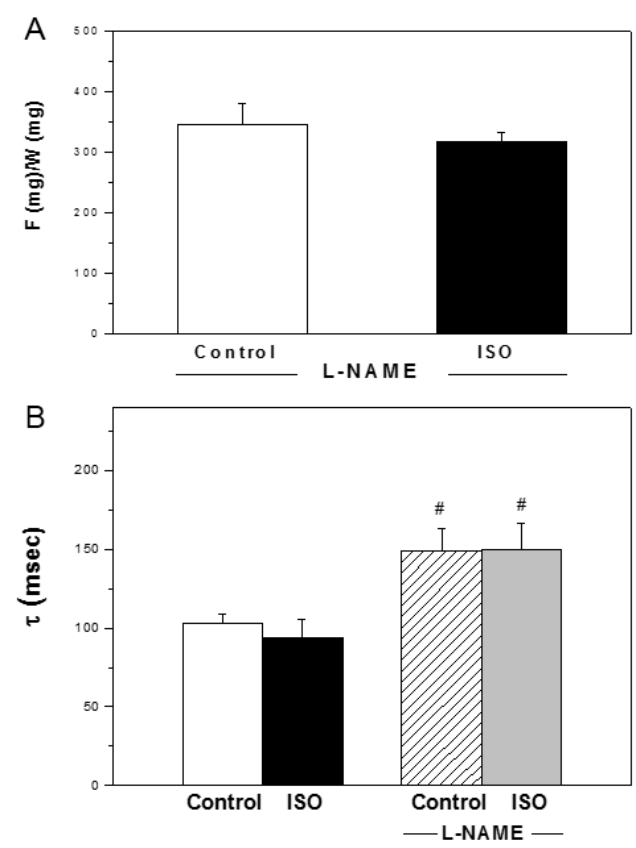

Figure 2. Average results of maximal force of contraction $(\mathrm{F} / \mathrm{W}, \mathrm{A})$ and $\tau(\mathrm{B})$ for control and ISO aortic rings in presence of L-NAME. \# $\mathrm{p}<0.05$ with vs without L-NAME. 


\section{DISCUSSION}

This study demonstrates by the first time that the monoterpene isolated from the leaves of Oxandra of xylopioides isoespintanol attenuates the contraction of aortic rings induced by high potassium and does not modify the magnitude and velocity of relaxation. Our data also show that the vascular effect of ISO was abolished by NOS inhibition with L-NAME.

Contraction in vascular smooth muscle can be initiated by mechanical, electrical, and chemical stimuli. Electrical depolarization of the vascular smooth muscle cell membrane (as produced by $80 \mathrm{mM} \mathrm{KCl}$ ) elicits contraction by increasing the intracellular $\mathrm{Ca}^{2+}$ concentration, most likely by opening voltage dependent $\mathrm{Ca}^{2+}$ channels (L-type $\mathrm{Ca}^{2+}$ channels) (10). Accumulating evidence suggests that the transient receptor potential (TRP) channels modulate the driving force for $\mathrm{Ca}^{2+}$ entry through L-type $\mathrm{Ca}^{2+}$ channels and provide intracellular pathways for $\mathrm{Ca}^{2+}$ release from cellular organelles, thus increasing the intracellular $\mathrm{Ca}^{2+}$ concentration (11). The free $\mathrm{Ca}^{2+}$ binds to calmodulin and the complex $\mathrm{Ca}^{2+}$-calmodulin leads to myosin light chains (MLC) phosphorylation, then cross-bridge formation, and hence, smooth muscle contraction. Enhanced $\mathrm{Ca}^{2+}$ entry via upregulation of TRP or L-type voltage-dependent $\mathrm{Ca}^{2+}$ channels represent a critical mechanism involved in the development of pulmonary and systemic hypertension (12). In our experiments, isoespintanol attenuated the contractile force generated by $80 \mathrm{mM} \mathrm{KCl}$ suggesting that a lesser activation of $\mathrm{Ca}^{2+}$ channels and a reduction of intracellular $\mathrm{Ca}^{2+}$ concentration could be taking place in comparison to control.

Vascular smooth muscle relaxation occurs when there is reduced phosphorylation of MLC that can result from a reduction of $\mathrm{Ca}^{2+}$ or activation of phosphatase among other causes. Several members of TRP family such as TRP canonical type 3 channels have also been involved in this process (13-15). In this study, isoespintanol did not modify the aortic relaxation suggesting that this drug do not have any action on its involved mechanisms.

The eNOS-mediated signal pathway in vascular tissue has been well established (16). This enzyme synthesizes $\mathrm{NO}$ in a pulsatile manner and its activity markedly increases when intracellular $\mathrm{Ca}^{2+}$ rises (17). NO acting through cGMP can stimulate a cGMP-dependent protein kinase (cGK) that activates MLC phosphatase and also can inhibit $\mathrm{Ca}^{2+}$ entry through L-type $\mathrm{Ca}^{2+}(18)$ or/and TRP channels (19). Both actions lead to smooth muscle relaxation. Our data show that the decreased contraction force achieved by isoespintanol was abolished by L-NAME treatment indicating that NO participates in the vascular effects of that compound.

One of the major groups of biologically active phytochemicals is the terpenes. These compounds are mostly hydrocarbon in nature and their building block is a five-carbon isoprene unit. The structure of most terpenes consist of 'head-to-tail' condensation of isoprene units and they are classified according to the number of isoprene units. Consequently, there are monoterpenes, diterpenes, triterpenes, etc, (20). Earlier studies have shown that both monoterpenes and their synthetic derivatives possess a variety of pharmacological properties through modulation of activities of various ion channels (21). In this sense, previous investigations show that changes of $\mathrm{Ca}^{2+}$ influx via TRP channels are involved in the vascular effects of monoterpenes carvacrol and menthol (22, 23). Our data does not allow us to evaluate any action of isoespintanol on TRP and/or L-type $\mathrm{Ca}^{2+}$ channels. Knowing the important role of $\mathrm{Ca}^{2+}$ in the smooth muscle contraction-relaxation cycle we only can speculate that in presence of isoespintanol the intracellular $\mathrm{Ca}^{2+}$ concentration must be lower than in absent of the compound.

Vascular function can also be regulated through several types of potassium channels, expressed not only on sarcolemma but also on endothelial layer. It has been demonstrated that a high level of depolarization (induced by high $\mathrm{KCl}$ ) produced a reduction in the potency and efficacy of drugs activating potassium channels (24).

Considering the important roles of ion channels in cardiovascular disorders (25), further investigations on the effects of isoespintanol on the functional properties of these channels could enable its utilization as a preventive therapy of those pathologies.

\section{CONCLUSIONS}

Our results show that pretreatment with isoespintanol produces a relaxant effect on aorta that was significantly attenuated by NOS inhibition with L-NAME. 
Therefore, our findings propose that isoespintanol acting on endothelial TRP channels and/or membrane receptors induces $\mathrm{Ca}^{2+}$-mediated eNOS activation and a consequent increase of $\mathrm{NO}$ production. This molecule reaches the smooth muscle cell and decreases the $\mathrm{Ca}^{2+}$ concentration (through TRP or/and L-type $\mathrm{Ca}^{2+}$ channels) thus leading to vasorelaxation (Figure 3).

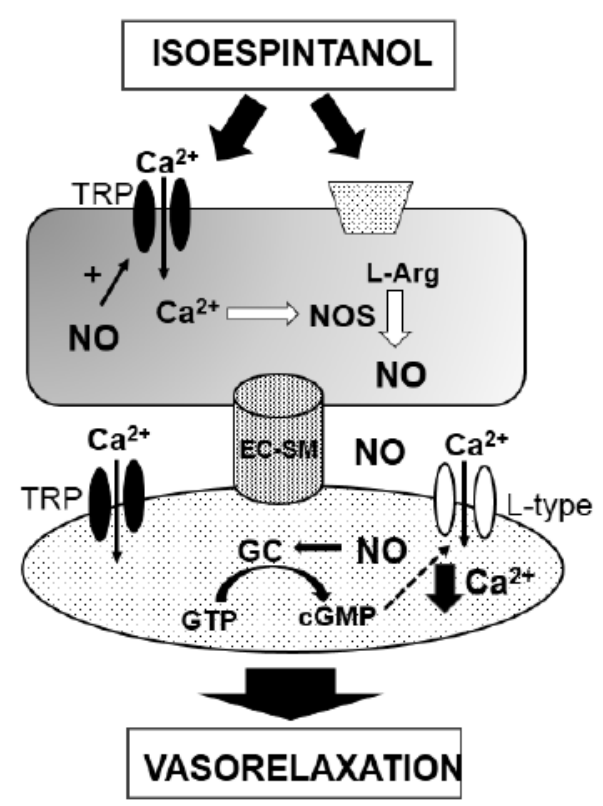

Figure 3. Possible mechanisms involved in the vascular actions of isoespintanol. TRP: Transient receptor potential channels; EC: Endothelial cell; SM: smooth muscle.

Although the in vitro model is very useful and simple to assess the vascular actions of new drugs or compounds more data are needed, especially human intervention studies, to extend the present knowledge to clinical area.

\section{CONFLICT OF INTEREST}

We wish to confirm that there are no known conflicts of interest associated with this publication and there has been no significant financial support for this work that could have influenced its outcome. We confirm that we have given due consideration to the protection of intellectual property associated with this work and that there are no impediments to publication, including the timing of publication, with respect to intellectual property. In so doing we confirm that we have followed the regulations of our institutions concerning intellectual property.

\section{ACKNOWLEDGEMENTS}

This study was supported by the Grant M-203 from the National University of La Plata of Argentina to Dr. Susana M. Mosca.

\section{AUTHORS` CONTRIBUTIONS}

G.J.R. and S.M.M. performed the experiments and data analysis; B.R. isolated and identified the isoespintanol; S.M.M. and G.S. designed the research and wrote the manuscript.

\section{REFERENCES}

1. Gutierrez DA, Fernandez-Tenorio M, Ogrodnik J, Niggli E. NO-dependent CaMKII activation during $\beta$-adrenergic stimulation of cardiac muscle. Cardiovasc Res. 2013; 100(3): 392-401.

2. Félétou M, Köhler R, Vanhoutte PM. Nitric oxide: orchestrator of endothelium-dependent responses. Ann Med. 2012; 44(7): 694-716.

3. Khalil RA, Van Breemen C. Mechanisms of calcium mobilization and homeostasis in vascular smooth muscle and their relevance to hypertension. In: Laragh JH, Brenner BM, eds. Hypertension: Pathophysiology, Diagnosis and Management. New York, Raven Press, 1995.

4. Atanasov AG, Waltenberger B, Pferschy-Wenzig EM et al. Discovery and resupply of pharmacologically active plant-derived natural products: A review. Biotechnol Adv. 2015; 33(8): 15821614.

5. Wagner KH, Elmadfa I. Biological relevance of terpenoids. Overview focusing on mono-, di- and tetraterpenes. Ann Nutr Metab. 2003; 47(3-4): 95-106.

6. Márcio RV, Santos MRV, Moreira FV, et al. Cardiovascular effects of monoterpenes: a review. Rev Bras Farmacogn. 2011; 21(4): 764-71.

7. Rojano B, Pérez E, Figadère B, et al. Constituents of Oxandra cf. xylopioides with anti-inflammatory activity. J Nat Prod. 2007; 70(5): 835-38.

8. Rojano BA, Gaviria CA, Gil MA, et al. Actividad antioxidante del isoespintanol en diferentes medios. Vitae 2008; 15 (1):173-81.

9. Rameshrad M, Babaei H, Azarmi Y, et al. Rat aorta as a pharmacological tool for in vitro and in vivo studies. Life Sci 2016; 145: 190-204.

10. Kravtsov GM, Bruce IC, Wong TM et al. A new view of $\mathrm{K}^{+}-$ induced contraction in rat aorta: the role of $\mathrm{Ca}^{2+}$ binding. Pflugers Arch. 2003; 446(5): 529-40.

11. Guibert C, Ducret T, Savineau JP. Expression and physiological roles of TRP channels in smooth muscle cells. Adv. Exp. Med. Biol. 2011; 704: 687-706.

12. Earley S, Brayden JE. Transient receptor potential channels in the vasculature. Physiol Rev. 2015; 95(2):645-90.

13. Zhang DX, Gutterman DD. Transient receptor potential channel activation and endothelium-dependent dilation in the systemic circulation. J Cardiovasc Pharmacol. 2011; 57(2): 133-39.

14. Alonso-Carbajo L, Kecskes M, Jacobs G, et al. Muscling in on TRP channels in vascular smooth muscle cells and cardiomyocytes. Cell Calcium 2017; 66: 48-61.

15. Grayson TH, Murphy TV, Sandow SL. Transient receptor potential canonical type 3 channels: Interactions, role and relevance - A vascular focus. Pharmacol Ther. 2017; 174: 79-96.

16. Förstermann U, Sessa WC. Nitric oxide synthases: regulation and function. Eur Heart J. 2012; 33: 829-37. 
17. Favero G, Paganelli C, Buffoli B, et al. Endothelium and its alterations in cardiovascular diseases: life style intervention. Biomed Res Int. 2014; 2014: 801896.

18. Blatter LA, Wier WG. Nitric oxide decreases $\left[\mathrm{Ca}^{2+}\right]_{\mathrm{i}}$ in vascular smooth muscle by inhibition of the calcium current. Cell Calcium 1994; 15(2): 122-131.

19. Dietrich A, Kalwa H, Gudermann T. TRPC channels in vascular cell function. Thromb Haemost. 2010; 103: 262-70.

20. Gershenzon J, Dudareva N. The function of terpene natural products in the natural world. Nat Chem Biol. 2007;3(7): 408-14.

21. Oz M, Lozon Y, Sultan AS, et al. Effects of monoterpenes on ion channels of excitable cells. Pharmacol Ther. 2015; 152: 83-97.

22. Earley S, Gonzales AL, Garcia ZI. A dietary agonist of transient receptor potential cation channel V3 elicits endotheliumdependent vasodilation. Mol Pharmacol. 2010; 77(4): 612-20.
23. Melanaphy D, Johnson CD, Kustov MV, et al. Ion channel mechanisms of rat tail artery contraction-relaxation by menthol involving, respectively, TRPM8 activation and L-type $\mathrm{Ca}^{2+}$ channel inhibition. Am J Physiol Heart Circ Physiol. 2016; 311(6): H1416-30.

24. Testai L, Chericoni S, Martelli A, et al. Voltage-operated potassium $(\mathrm{Kv})$ channels contribute to endothelium-dependent vasorelaxation of carvacrol on rat aorta. J. Pharm. Pharmacol. 2016; 68(9), 1177-83.

25. Vanhoutte PM, Shimokawa H, Feletou M, et al. Endothelial dysfunction and vascular disease - a 30th anniversary update. Acta Physiol. (Oxf). 2017; 219(1): 22-96. 